\title{
Racism and Islamophobia: A Personal Perspective
}

\author{
Amir Saeed \\ University of Huddersfield, School of Music, Humanities and Media
}

\begin{abstract}
The article employs a subjective personal approach to show that new racisms are alive in the twenty-first century. Tracing my parents' journey from India and Pakistan to Britain, it explores the political effects of the racism they and their children faced. Locating these reflections in a post-9/11 world, the article describes the turn my academic work has taken in response to media representations of Muslims, and calls for academic research on British Muslim identity to reflect the process of identity-making and its contingencies.
\end{abstract}

Key words: Racism, Islamophobia, 'race', Islam, Muslims, culture

The West saw itself as a spiritual adventure. It is in the name of the spirit, in the name of the spirit of Europe, that Europe has made her encroachments, that she has justified her crimes and legitimized the slavery in which she holds four-fifths of humanity. Yes, the European spirit has strange roots.

(Fanon, 1986: 252)

\section{Situating a Personal Perspective}

This article examines how the resurgence of Islamophobia in contemporary society has its roots in the concept of 'race' and the evolution of racism. To understand this, these issues are presented via a personal perspective to help the reader comprehend the human impact that racism has in society. Hence the growing academic literature on contemporary racism is approached and debated by employing a subjective evaluation.

Given that academia is supposed to be rational, objective and scientific, the approach and conclusions may be open to criticism. However the writing of As'ad AbuKhalil (describing his most recent book on Bin Laden, Terrorism and Islam) may provide some thought to critics of a subjective approach:

The style and tone of this book are emotional, and may strike the academic reader as odd. But hiding behind the cloak of objectivity is often used more to conceal than to reveal.

(2002: 11)

In contrast to much mainstream research that generally seeks to attain value 
neutrality, feminist researchers will often integrate personal experiences into their research. Personal experiences are not perceived as making the methods and results of research worthless. Rather, many feminists view it as serving to validate their research:

Feminist women must deliberately ... integrate their repressed, unconscious female subjectivity, i.e. their own experience of oppression and discrimination into the research process.

(Maria Mies in Reinharz, 1992: 263).

At the heart of much feminist research is the goal, even the obligation, of taking action and bringing about change in the condition of women. Whether a researcher recommends explicit policy recommendations or less overtly offers social implications of his or her findings, this focus on creating social change appears to be a theme across much of feminist thought (Reinharz, 1992: 251). Collins describes her own position in her research as very personal:

I often use the pronoun 'our' instead of 'their' when referring to African-American women, a choice that embeds me in the group I am studying instead of distancing me from it. In addition, I occasionally place my own concrete experiences in the text.

(1990: 202)

Reinharz (1992) notes that feminist researchers may use these experiences to inform their research questions, to guide their involvement in the research process, and to help test and interpret results. In this way, their own personal experiences appear to be an asset in their work.

Thus by employing a subjective personal approach this article will show that ideas of 'race' and racism are still alive in the new millennium. Unfortunately racism and new racisms still exist in the current era. At times these ideas are based on crude almost biological notions of inferiority and superiority. These exist alongside more subtle notions of 'inclusion' and 'exclusion' that determine who are 'the wretched of the earth' (Fanon, 1961).

\section{Encountering Racism}

The mode of production of material life conditions the general processes of social, political and intellectual life. It is not the consciousness of men that determines their existence, but their social existence that determines their consciousness.

(Marx and Engels, 1968: 173; my emphasis)

A personal example may help illustrate this point. My father was born In India, my mother in Pakistan. After the partition of India in 1947, my father, a Muslim, 
migrated to Pakistan. The fact that 1,000,000 Indians died in this period of sectarian conflict is important (Modood, 2006). At that point, conflict with the 'white Master' (the British) was replaced by inter-ethnic conflict mainly along religious lines.

In 1956, my father (leaving my mother and brothers and sisters behind in Pakistan) joined the millions of other people (predominately young men at this stage) to search for a 'better' life in the West. On arriving in the UK, my father's hope was replaced by fear, suspicion and an almost subservient attitude towards whites. Facing the brunt of verbal and physical racism my father was then introduced to institutional racism, taking a variety of menial, labouring jobs that even the white working class refused. Academics would refer to my father has one of the 'reserve army of labour' (Miles, 1993).

Years later, the Labour Prime Minister Gordon Brown would echo a neofascist slogan and lament 'British jobs for British workers' (Saeed, 2010; 2007). More recently the current Labour leader has promised to tighten immigration laws and protect 'British workers' (BBC, 2014). It seems that the 'race' card is employed even by liberal politicians and this makes me wonder at what point will I ever be accepted as 'British' by the establishment.

The 'myth of return' (Saeed et al, 1999) did not materialise, and as my siblings came to the UK we settled into life. Racism was a daily occurrence. Physical and verbal abuse a constant. The ignorance of our attackers at times even provided grounds for amusement. For example, being called, 'Ethiopian', 'African', 'nigger', 'darkie' and, of course, 'Paki'. Various ethnic and national terms were deployed, none of them delivered in a complimentary manner.

We were not seen as British nor Scottish (Saeed et al, 1999), just as 'immigrants', and suffered the racist connotations of that term. In a similar vein, Balibar writes:

The racial-cultural identity of 'true nationals' remains invisible, but can be inferred (and is ensured) a contrario by the alleged, quasi-hallucinatory visibility of the 'false nationals': the Jews, 'wogs', immigrants, 'Pakis', natives and blacks.

(Balibar and Wallerstein, 1991: p. 60)

In contrast to the 'true nationals' who threw out this abuse, due to our skin colour our nationality was 'false', despite us living, working, and growing up in the UK.

Entering the workforce, a new racism was encountered. Desperation at being offered menial jobs meant the only avenue to attain economic affluence was through self-employment. Whilst economic hardship could be challenged, pervasive cultural racism was harder to break. Ethnically 'Pakis' were the brunt of street humour, and, of course, more seriously 'paki bashing'. Politically, our presence was questioned in the UK and culturally our religion/customs were seen as a threat, uncivilised or openly ridiculed (Saeed, 2004; 2007a; b).

Whilst those guilty of overt racism were chastised by political and social commentators, 'racist' thinking that implied the problem was with migrant 
communities was widely employed (Bates and Saeed, 2009). Thus policies were designed on how best to 'manage' migrants rather than dealing with the root causes of racism.

At the same time, this story was mirrored millions of times over, not just by migrants from India but by people moving across borders throughout the world to enter former colonial powers.

In dealing with racism, our family tried to achieve economic independence, thinking that monetary and capital affluence may deaden the abuse. Whilst this may have worked in some respects, it was not completely successful. Cultural racism was challenged through greater self-pride and an interest in global anti-racist movements. Thus people like Muhammad Ali, Malcolm X, Nelson Mandela and even the PLO leader Yasser Arafat entered our family domain through the medium of global communications (Saeed, 2014a,b; 2007; 2004; 2002). Whilst the AfricanAmerican, South African and Palestinian histories (Drainville and Saeed, 2013; 2011) have their own stories, what became evident were the common threads of racism, imperialism and exploitation. Thus the inter ethnic genocide of 1947 in India was reformulated by my family into the broader global context of anti-imperialist struggle and related to the demands for equality by young Africans in townships of Soweto.

Thus our (my family's) consciousness was determined by our understanding of racism within the global context of power relations. The words of Malcolm X were particularly relevant (Saeed, 2014a; 2007):

And just you see the oppressed people all over the world today getting together, the Black people in the West are also seeing that they are oppressed. Instead of just calling themselves an oppressed minority in the states, they are part of the oppressed masses of people all over the world today who are crying out for action against the common oppressor.

February 11, 1965 (cited in Saeed, 2007c: 13)

In many respects, my political identity was modelled around inclusive definitions of 'black.' I understood the term 'black' as meaning people of Third World origin who were victims of European imperialism whether they were Latin American, African or Asian; to me they were part of the colonised globe and thus deserved my support.

My citizenship responsibilities entitled me to be at least part British or Scottish. Indeed the notion of hybridity was my initial research area in academia. From national identity to sport to music, my research was initially focused on how minority groups adapted to, accepted, challenged and formulated cultures (of incorporation and resistance) within a different context. The events of 9/11 and the subsequent levels of hostility have made me question my own notion of hybridity. Increasingly, I experience and see Muslims having to emphasise their Britishness. It seems they are given a stark choice: be British or be Muslim. In short, they are expected to assimilate not just integrate (Saeed, 2004). 
It is with this personal background that I have to approach any further research within race and ethnic studies.

\section{'Race': A Social Scientific Dilemma}

'Race' only exists as a concept, yet belief in social construct leads to the direct and indirect discrimination, abuse and suffering of billions of people on Earth daily, hourly, and by the second. Across the globe, racism manifests itself in various ways that ensures people are victimised on the basis of some hallucinatory negative biological and/or cultural trait that they are supposed to possess. Any attempt to explain comprehensively global accounts of the immediacy, currency and future of racism is virtually impossible, since the institutional structures, types, targets and experiences are potentially so vast and full of regional, local and national variations that dispute and debate will be inevitable. What cannot be disputed is that human beings will suffer. In short the racism faced by an asylum seeker on the streets in the north-east of England by a fascist group (Saeed, 2007b) will be visibly different from the persecution faced by a Palestinian woman by the occupying Israeli army in the Gaza strip (Saeed, 2009; Drainville and Saeed, 2011; 2013). Once again, both racisms have similar essential characteristics but both are also different due to epoch and institutional factors.

Although there is a growing body of evidence that discredits the notion of 'race', 'race' thinking still permeates much of Western culture. It is routinely used by politicians, media workers, academics and laypeople from a variety of backgrounds to describe, ascribe and, at times, disparage groups of people. As Malik argues:

Race seems to be both everywhere and nowhere. ... We continually categorise people according to their 'race' - Afro-Caribbean, white, Jewish. Discussions of culture, history or art often seem to centre around race-'Asian culture', 'black history', 'African art'. Everything from criminality to the entrepreneurial spirit is given a racial connotation-witness the stereotypes of 'black muggers' or 'Asian shopkeepers'.

(1996: 2)

Hall (1996) has suggested that 'race' has become a 'floating signifier'; as a result, it has become entwined within elements of biology, culture, religion and nation, making it difficult to expel from everyday discourse. The significant marker for 'race' is skin colour and the connotations that it implies. However, as Cole (2009) indicates, modern racism in the UK also attacks othered white groups.

One could suggest that if 'race' discourse is upheld in everyday language, the problematic ideology of racial difference will continue to live on. What we must remember is that 'racial' differences are social inventions, not natural. Thus, 'races do not exist outside representation but are formed in and by it in a process of social 
and political struggle' (Barker, 1999: 61). This has led some to argue that 'today the race concept is more problematic than ever before' (Winant, 2009: 67-8).

As Meer and Nayak eloquently note:

race is very much installed in the here and now. It remains ever present in latemodernity and strangely solid in liquid times.

Thus, despite the ambiguous nature and problematic history of 'race' in contemporary modern and global society, essentialized 'race' thinking still appeals to significant sections of humanity. This leads to racism.

\section{Racism}

Where there is 'race', there is racism. If 'race' and racism have strong currency in today's world, then the study of their impacts upon society is of vital importance. As Solomos notes:

At the beginning of the twenty-first century it is clear that there has been a major transformation in this field and a noticeable flowering of theorising and research on race and racism. It is also evident that the study of race and racism is now of some importance in a wide range of academic disciplines, including sociology, politics, cultural studies, history, anthropology, geography and literary theory.

(2003: 1)

For Miles 'race' is an ideological construct, and it is only in certain historical conjunctures and under certain material conditions that some groups find it necessary to create a 'racialised Other' (simultaneously racialising themselves) in order to differentiate, exclude and dominate (1993: 44). Miles urges us to think of 'race' and 'racism' not as concepts that are rigid and fixed but rather as ones that constantly change and evolve according to different social, political and historical contexts. Race and racism thus go 'hand in hand.'

It has been argued that new forms of racism have emerged within contemporary society (Barker, 1981; Gilroy, 1993; Mason, 2000). Goldberg (1990: xiii) argues that 'the presumption of a single monolithic racism is being displaced by a mapping of the multifarious historical formulations of racisms'. Thus, traditional forms of racism linked to biological difference have perhaps become out-dated as racism has now attached itself to cultural differences between racial or ethnic groups. Pilkington (2003: 18) notes that 'in the case of new racism race is coded as culture'. Hence, 
the question of cultural production and the politics of identity are fast becoming an important area of contemporary debate.

(Back and Solomos, 2000: 19)

It is more appropriate, then, to speak of 'racisms' - as Miles puts it, 'different modalities of racism within the historical matrix mapped by the evolution of the capitalist mode of production and by the associated rise of the nation state.' (1993: 26). Or to use Balibar and Wallerstein words, racisms are 'ever active formations' which materialise in any number of 'historical trajectories.' (Balibar \& Wallerstein 1991: 40). As we shall see below, the historical trajectory has resulted in the development of anti-Muslim racism commonly associated with the term 'Islamophobia.'

\section{Islamophobia}

Elizabeth Poole (2002) describes how this contemporary manifestation of racism has its roots in Orientalist discourse and constructions of the 'other'. The word 'Islamophobia' has been coined because there is a new reality which needs naming: anti-Muslim prejudice has grown so considerably and so rapidly in recent years that a new item in the vocabulary is needed (Runnymede Trust, 1997: 4). Weedon describes Islamophobia as 'unfounded hostility towards Islam ... unfair discrimination against Muslims individuals and communities' (2004: 165). It could be argued that Islamophobia came about because of a desire, by Western powers, to prolong the ideology of white or Western supremacy:

Claims that Islam is totally different and other often involve stereotypes and claims about 'us' (non-Muslims) as well as about 'them' (Muslims), and the notion that 'we' are superior. 'We' are civilised, reasonable, generous, efficient, sophisticated, enlightened, non-sexist. 'They' are primitive, violent, irrational, scheming, disorganised, oppressive.

(Runnymede Trust, 1997: 6)

Much literature has debated the term, its definition and the extent of Islamophobia in society in recent years (Allen, 2010; Esposito and Kalin, 2011; Poynting and Mason, 2007; Sayyid and Vakil, 2011). Meer (2013) and Mossavi (2013) do note the contentious nature of the term and suggest that some authors think the term is inaccurate. For Halliday, the term 'Islamophobia' is inaccurate because it is too uniform. Halliday (1999) points out that usage of this term implies that there is only one Islam and that all Muslims are homogenous. In short, Halliday (1999: 898) is proposing that Islamophobia as a term suggests fear of Islam as a religion not fear of the people who follow Islam (Meer, 2013). However, Halliday does acknowledge that such academic debates might not prove fruitful for victims of such prejudice. 
Furthermore, Fekete (2002) and AbuKahlil (2002) point out that, post 9/11, some of the critics of Muslims have actually questioned the Islamic concepts of jihad and the hadiths of the Prophet Muhammad.

Studies have examined this prejudice from a variety of perspectives in society. Researchers have noted the willingness of mainstream politicians to employ Islamophobic statements (Mossavi, 2014). These have indicated that mainstream politicians regard Muslim minorities, and at times Islam, as a threat to Western secular democracy and, indeed, regard Muslims as the 'minority' that is a risk to multiculturalism and integration (Saeed, 2010; Meer, 2010; Modood, 2006). The negative reaction to many of the religious and cultural practices of British Muslim communities among white Britons has been identified in public policy discourse as symptomatic of the failure of British multiculturalism that is blamed on Muslim minority groups (Hussain and Bagguley, 2003).

Furthermore, the apparent willingness of these Muslim 'enemies within' to support terrorism abroad (Saeed, 2004) and develop an ideology that appears to challenge 'Western democracy' has seen Muslim minority groups placed under greater scrutiny by governments, public bodies and judicial organisations across the West (Abbas, 2012). Kundnani (2008) has described the way in which Muslims have been singled out as the culturally distinct minority whose difference is constructed as a threat to national cohesion and security. Indeed much policy research in relation to Muslim communities is focused on the 'Preventing Violent Extremism' agenda (Miah, 2013; Birt, 2009; Khan, 2009).

Muslims have effectively been told not only that they must make a special effort to integrate but also that they must assume collective responsibility for the terrorist actions carried out in the UK and elsewhere in the name of the Islamic faith (Saeed 2004: 71). Empirical work in this area underlines this, with Ahmed noting, in a series of interviews with young Muslims, that they

feel strong attachment to their society, but many feel that they are not fully accepted as British, and frequently have to prove their loyalty. Often they are faced with questions that imply a choice between their religion and their British citizenship and popular perception is that the two are somehow conflicted or incompatible.

(Ahmed, 2009: 81)

Significantly, the Runnymede Trust also appeals to the media to acknowledge their role in the reproduction of Islamophobia. Various authors have noted that often Islam and Muslims are treated homogenously in Western media and depicted as the opposite of the West (Saeed, 2007; Akbarzadeh and Smith, 2005; Halliday, 1999; Poole, 2002; Runnymede Trust, 1997; Sardar and Davis, 2002). There is a complexity of reasons why the Western media has a certain unsympathetic view of Islam (Poole and Richardson, 2006). Said (1978) argues that the main reason for this is that the West has its own 'experts' (reporters, commentators, academics/scholars, etc.) commenting on Islam, making statements about it, explaining it, and so on. The 
problem, he says, is that 'we' the West, represent 'them' (the East), hence, 'they' are not representing 'themselves'. Saeed and Drainville argue that such

binary conceptions not only depict all things oriental as 'other', but also define Islam as the 'other' religion to Christianity. With the 'other' constantly described as inferior, even barbaric, it is easily accepted by a Western audience that terrorism stems from Islam.

Solomos (2003: 186) suggests that this follows a wider tradition of media representations that depict ethnic minority communities as 'endangering the cultural and political values of the nation'. The news media's focus on non-white immigration into the UK and other parts of Europe has re-awakened debates of 'otherness' and 'culture clash'. Too often, these debates ignore the reality of the existence of marginalized groups and concentrate on the 'fear of the outsider' rather than on the contribution immigrants can make. This homogenization of 'otherness' and stereotyping, however, generates fear, contempt and hatred of the groups deemed 'other': non-whites, Muslims, asylum seekers, etc.

Mills et al (2011) highlight the importance of powerful right-wing think tanks that have successfully managed to influence the mainstream media with a succession of 'Muslim scare stories' that suggest Muslims in the UK are attempting to undermine secular democratic institutions ranging from local governments to Higher education.

It is important to acknowledge that, while Islamophobia may be triggered by skin colour, this is not always the case; it can also be set off by one or more (perceived) symbols of the Muslim faith. As Sivanandan puts it, referring to British Muslims as 'the terrorist within' ensures that 'the victims are marked out not so much by their colour as by their beards and headscarves' (Sivanandan 2009: ix). This follows Amin's assertion that, as part of discourses constructing the 'War on Terror',

'phonotypical' evaluations new upon old returned to typecast the Asians ... along with Muslims elsewhere in Britain, as cultural aliens and national threats. Pinning new aversions such as anxiety, suspicion, fear and hate to local Muslims has relied ... on linking vicariously constructed phenotypes (including prayer caps, beards, baggy trousers, rucksacks, Yorkshire accents, loud music, shiny cars and shabby dwellings) to terrorism, radical Islam, sexual slavery, drug trafficking and cultural backwardness.

(2010: 8)

An increasing mass of research suggests that Muslims themselves consider the news and mainstream media to 'misrepresent' or to represent them unfairly, and for that to be an important aspect causing discrimination and/or a lack of understanding between communities (Saeed, 2011; Fekete, 2009).

At the same time, evidence from the Home Office and independent research 
suggests that violence and discrimination towards Muslims, already significant pre 9/11, has indeed evidently increased (Allen and Nielsen, 2002; Fekete, 2009). The growth of the Far Right across Europe and the return of street violence and racism directed towards Muslims (or even victims perceived to be Muslims) (MeleagrouHitchens and Brun 2013; Saeed, 2011; Kundnani, 2007) has seen Muslims across Europe feeling that they are in a midst of a cultural, social and political siege.

\section{The Muslim Response}

Whilst the mainstream media suggest that disenfranchised Muslims are inclined to turn to fundamentalist interpretations of Islam, in many respects this has not been the case. Despite the negative connotations attributed to Muslims' 'radicalism', a survey of British Muslims undertaken by the 1990 Trust in 2006 found that whilst $82 \%$ of its respondents thought that Muslims were becoming more radicalised, a majority $(65.2 \%)$ crucially did not associate radicalism with violence. Instead, radicalism was primarily associated more with activities such as letter writing, demonstrations, becoming involved in organisations or disengaging with mainstream politics (1990 Trust, 2006).

In fact, as Mahamdallie (2007) has argued, there exists in Britain a long and proud history of radical working-class struggle by Muslims and other non-white minorities. In spite of the political and cultural onslaught, more and more Muslims are attempting to engage with radical politics. British Muslims have affirmed their political vibrancy and diversity in a number of other ways. Thousands of British Muslims took part in the million-strong multicultural demonstration against the Iraq war in London in February 2003 (Saeed, 2004). Indeed Muslims are identifying new reflexive spaces in various aspects of the public and social sphere (Meer and Modood 2009), for example, the rise of the Muslim 'blogo-sphere' and employment of new/social media to challenge anti-Muslim perceptions (Saeed, 2014). Furthermore, the willingness of young Muslims to create cultural outlets from art, to music, to even fashion, shows how a young dynamic Muslim popular culture is being created that shows the willingness of Muslims to integrate, adapt and be involved in all aspects of society (Saeed, 2014).

For Sadek,

It is important also to note that despite evidence of increasing religiosity among British Muslim young people ... the majority remain only 'cultural Muslims', that is to say non-observant, practising their faith only very occasionally.

Furthermore, just as evidence seems to indicate that young people are less likely to be politically motivated, Muslims are the embodiment of active 'citizens' (Wayne et al, 2010) in the modern new media public sphere. Indeed, younger Muslims across 
Europe are employing new media to display an identity politics that is assertive. Muslims in Europe are attempting to create cultural, social and political spaces for themselves as ethnic and religious groups and are also at the forefront of anti-racist and anti-imperialist mobilizations. Young, European Muslims have employed new media to challenge Islamophobic statements and also re-claim Islam from the fundamentalists (Kilvington et al, 2014).

Simultaneously, the argument that Muslims are a threat to multiculturalism can be challenged by a cursory glance at contemporary European popular culture. From sport to music to film it can be easily shown that young European Muslims are at the forefront of cultural change and indeed integration (Saeed, 2014). Hamid (2011) notes that Muslim youth sub-cultures exist in diverse fields such as fashion to heavy metal.

\section{Concluding comments -Identity Matters}

Since the events of 9/11 and the subsequent 'War on Terror', it could be argued that Muslims are now treated as the dominant threat to British society. Similar to other racialised groups, various authors contend that the media represent Muslims as one homogenous uncivilized group, with mass generalisations that often depict Muslims as terrorists or Islamic extremists (Saeed 2004; 2007a; b).

The events surrounding 9/11, especially the War on Terror, have made me make closer and closer examination of my religious roots. My secular outlook, in recent months, has been replaced by a more religious, and (I say so hesitantly) more Islamic perspective. Rather than seeing Islam just as a religion, closer examination of the Koran for me showed that it was a political ideology that could provide a framework for me to understand contemporary capitalist society. For many, capitalism is inherently unjust and unequal; for me capitalism quite simply (using the classic socialist phrase) puts 'profit before people'. Whilst popular culture and public opinion seemed to decry the inhumane nature of Islam following 9/11 the following passage from the Koran seemed to problematize that stereotype:

Whoever slays a soul ..., it is as though he slew all mankind, and whoever keeps it alive it is as though he kept alive all mankind.

(Al Quran 5: 35)

In Islam, it was clear to me, life was to be respected and the right to life to be accorded to all beings; unfortunately, those who appeared to be the strongest critics of Islam seemed to have the weakest knowledge of it.

More and more Muslims, it appears, are now facing the same challenges by drawing strength from an Islamic identity that can provide solidarity with other Muslims (Saeed, 2003; 2004; Saeed at al, 1999). This Islamic challenge or struggle has been popularized in the media as intrinsically violent. For example, the use of the 
term 'jihad' conjures up images of violent, irrational terrorism. Yet jihad does not necessarily mean a call to arms and a prelude to bloodshed. A jihad can be personal and may include debate, reasoning, marching, and indeed voicing concern in a written format.

A progressive Islam centered on the inclusion of all disparaged groups (regardless of religion, ethnicity, and sexuality) is my jihad. At the genesis of Islam the main converts were slaves and women, the two most oppressed groups at the time. That they saw something liberating and empowering within the Hadiths (sayings/teachings) of the Prophet Muhammad (peace be upon him) illustrates for me that Islam has a liberal and radical foundation inherent in its teachings.

Yes I am becoming angrier, but at the same time I can see some optimistic signs as young Muslims become more politically active and this assertion is filtered through popular culture.

Identity is a fluid concept that is subject to change dependent upon situation and influence. What this article shows is that my identity has been greatly influenced by external factors and that this has had a major impact on my academic research as well as my personal identity. Identity should be though of as a process; it is a matter of becoming not just being (Hall, 1996).

In contemporary multicultural societies, academic research should acknowledge this process. In short, identity is an experience that is ongoing and research is required that highlights the importance of this. Fanon once called for

passionate research ... directed by the secret hope of discovering beyond the misery of today, beyond self-contempt, resignation and abjuration, some very beautiful and splendid era whose existence rehabilitates us both in regard to ourselves and in regard to others.

My own research has been grounded in academic methodology, but inspired by the real events around me. 9/11,7/7, the War on Terror, the constant negative attribution to Islam/Muslims in mainstream society, have inspired me to comprehend or at times expose the racism directed towards Muslims. I have attempted to give 'ordinary' Muslims (I include myself in this category) a voice that can show our common humanity.

\section{References}

1990 Trust. (2006). Muslim views: foreign policy and its effects. Survey. London: 1990 Trust.

Abbas, T. (2012). The symbiotic relationship between Islamophobia and radicalization. Critical Studies on Terrorism, 5 (3). doi:10.1080/17539153.2012.723448

AbuKhalil, A. (2002). Bin Laden, Islam and America's new 'War on Terrorism'. New York: Open Media. 
Ahmed, S. (2009). Seen and not heard: voices of young British Muslims. Leicester: Policy Research Centre, Islamic Foundation. Retrieved from http://www.islamic-foundation.org.uk/Resources/SeenandNotHeard-Complete.pdf.

Akbarzadeh, S. and Smith, B. (2005). The representation of Islam and Muslims in the media (The Age and Herald Sun Newspapers). Monash, Australia: Monash University Press. Report.

Allen, C. and Nielsen, J. (2002). Summary Report on Islamophobia in the EU after 11 September 2001. Vienna: European Monitoring Centre on Racism and Xenophobia. Report. Retrieved from http://fra.europa.eu/sites/default/files/fra uploads/199-Synthesis-report en.pdf.

Allen, C. (2010). Islamophobia. Aldershot: Ashgate.

Amin, A. (2010). The remainders of race. Theory, Culture and Society, 27 (1), 1-23. doi: $\underline{10.1177 / 0263276409350361}$

Back, L. and Solomos, J. (2000). Introduction: theorising race. In L. Back and J. Solomos (Eds.), Theories of Race and Racism: A Reader (pp. 1-28), Abingdon: Routledge.

Balibar, E. and Wallerstein, I. (1991). Race, nation, class: ambiguous identities.

London: Verso.

Barker, C. (1999). Television, globalization and cultural identities. Milton Keynes: Open University Press.

Barker, M. (1981). The new racism: Conservatives and the ideology of the tribe. London: Junction Books.

Bates, D., \& Saeed, A., (2009). Clashing the Civilisations. In J. Pugh (Ed.), What is radical politics today? (pp. 170-178). Basingstoke: Palgrave.

BBC. (2014). Miliband promises new immigration laws if he wins election. Retrieved from http://www.bbc.com/news/uk-politics-29742865.

Birt, Y. (2009). Promoting virulent envy? Reconsidering the UK's terrorist prevention strategy. The RUSI Journal, 154 (4 ), 52-58. doi: 10.1080/03071840903216460

Cole, M. (2009). A plethora of 'suitable enemies': British racism at the dawn of the twentyfirst century. Ethnic and Racial Studies, 32 (9), 1671-1685. doi: 10.1080/01419870903205556

Collins, P. (1990). Black feminist thought: knowledge, consciousness, and the politics of empowerment. Boston: UnwinHyman. 
Drainville, E. and Saeed, A. (2013). 'A Right to exist': a Palestinian speaks. Feminist Media Studies, 13 (5), 830-839. doi: 10.1080/14680777.2013.838364

Drainville, E., and Saeed,A. (2011). Filming Palestinian banality. Nebula: A Journal of Multidisciplinary Scholarship, 8 (1). Retrieved from http://www.nobleworld.biz/images/Drainville_and Saeed.pdf.

Esposito, J. L. and Kalin, I. (2011). Islamophobia: the challenge of pluralism in the 21st century. Oxford: Oxford University Press.

Fanon, F. (1961). The wretched of the earth. London: Grove.

Fanon, F. (1986). Black skin, white masks. London: Pluto.

Fekete, L. (2002). Racism, the hidden cost of September 11. London: Institute of Race Relations.

Fekete, L. (2009). A suitable enemy: racism, migration and Islamophobia in Europe. London: Pluto.

Gilroy, P. (1993). Small acts: thoughts on the politics of black cultures. London: Serpent's Tail.

Goldberg, D. (1990). The social formation of racist discourse. In D. Goldberg (Ed.), Anatomy of racism. Minneapolis, MN: University of Minnesota Press.

Halliday, F. (1999). 'Islamophobia' reconsidered. Ethnic and Racial Studies, 22 (5), 892-902. doi: $\underline{10.1080 / 014198799329305}$

Hamid, S. (2011). British Muslim young people: facts, features and religious trends. Religion, State and Society, 39 (2), 247-261. doi: 10.1080/09637494.2011.600582

Hussain, H. and Baugley, P. (2003). Citizenship, ethnicity and identity: British Pakistanis after the 2001 'riots'. Working paper, Department of Sociology and Social Policy, Leeds University. Retrieved from

http://www.leeds.ac.uk/sociology/people/pbdocs/Citizenship\%20working\%20paper.doc.

Jhally, S. and Hall, S. (1996). Race: the floating signifier. Northampton, MA: Media Education Foundation.

Khan, K. (2009). Preventing Violent Extremism (PVE) and PREVENT: a response from the Muslim community. London: An-Nisa Society. Report.

Kilvington, D., Farrington, N., Price, J. and Saeed, A. (2014). Social media, racism and sport. Abingdon: Routledge.

Kundnani, A. (2008). Integrationism: the politics of anti-Muslim racism. Race and Class, 48 (4), 24-44. doi: $\underline{10.1177 / 0306396807077069}$ 
Mahamdallie, H. (2003). Racism. In F. Reza (Ed.), Anti-imperialism: a guide for the movement (pp. 45-64). London: Bookmarks.

Malik, K. (1996). The meaning of race: race, history and culture in western society. Basingstoke: Palgrave.

Marx, K. (1968). Selected works. London: Lawrence \& Wishart.

Mason, D. (2000). Race and ethnicity in modern Britain. Oxford: Oxford University Press.

Meer, N. (2013). Semantics, scales and solidarities in the study of antisemitism and Islamophobia. Ethnic and Racial Studies, 36 (3), 500-515. doi: 10.1080/01419870.2013.734382

Meer, N. and Modood, T. (2009). The multicultural state we're in: Muslims, 'multiculture' and the 'civic re-balancing' of British multiculturalism. Political Studies, 57 (3), 473-497. doi: $\underline{10.1111 / j .1467-9248.2008 .00745 . x}$

Meer, N. and Nayak, A. (2013). Race ends where? Race, racism and contemporary sociology. Sociology. [published online before print]. doi: 10.1177/0038038513501943

Meer, N. (2010). Citizenship, identity and the politics of multiculturalism: the rise of Muslim consciousness. New York: Palgrave.

Meleagrou-Hitchens, A. and Brun, H. (2013). A neo-nationalist network: the English Defence League and Europe's counter-jihad movement. In partnership with the Swedish National Defence College and the Centre for Asymmetric Threat Studies (CATS). London: King's College. Report. Retrieved from http://icsr.info/wp-content/uploads/2013/03/ICSR-ECJMReport Online.pdf.

Miah, S. (2013). Muslim group solidarity and schooling. In Alexander, C., Redclift, V., and Hussain, A. (Eds.), The new Muslims. (pp. 23-25). London: Runnymede Trust. Retrieved from http://www.runnymedetrust.org/uploads/publications/Runnymede_The_New_Muslims_Pe rspective.pdf.

Miles, R. (1993). Racism after 'race relations'. Abingdon: Routledge.

Mills, T., Griffin, T., and Miller, D. (2011). The Cold War on British Muslims: an examination of Policy Exchange and the Centre for Social Cohesion. Glasgow: Spinwatch. Report. Retrieved from http://www.thecordobafoundation.com/attach/SpinwatchReport ColdWar12.pdf.

Modood, T. (2006). Multicultural politics: racism, ethnicity and Muslims in Britain. Edinburgh: Edinburgh University Press.

Mossavi, L. (2014). The racialization of Muslim converts in Britain and their experiences of Islamophobia. Critical Sociology, 41 (1), 41-56. doi: $10.1177 / 0896920513504601$

Mossavi, L. (2013). Orientalism at home: Islamophobia in the representations of Islam and 
Muslims by the New Labour government. Ethnicities. [published online before print run]. doi: $\underline{10.1177 / 1468796814525379}$

Pilkington, A. (2003). Racial and ethnic diversity in Britain. Basingstoke: Palgrave.

Poole, E. and Richardson, J. (2002). Muslims and the new media. London: I.B. Tauris.

Poynting, S. and Mason, V. (2007). The resistible rise of Islamophobia: Anti-Muslim racism in the UK and Australia before 11 September 2001. Journal of Sociology, 43 (1): 61-86. doi: $\underline{10.1177 / 1440783307073935}$

Reinharz, S. (1992). Feminist methods in social research. New York: Oxford University Press.

Runnymede Trust (1997). Islamophobia: a challenge for us all. London: Runnymede Trust.

Saeed, A. (2014a). Influences of Malcolm X on sports, music, and the global Muslim community. In A. Richards (Ed.), Muslims and American popular culture (pp. 57-71). New York: Praeger Press.

Saeed, A. (2014b). Between Hip-hop and Muhammad: European Muslim Hip-hop and identity. In G. Nash, K. Kerr-Koch and S. Hackett (Eds.), Postcolonialism and Islam: theory, literature, culture, society and film (pp. 181-192). Abingdon: Routledge.

Saeed, A. (2011a). 9/11 and the Increase in Racism and Islamophobia: A Personal Reflection. Radical History Review, 2011 (111), 210-215. doi: 10.1215/01636545-1268821

Saeed, A. (2011 b). 'Worthy of all praises': Muhammad Ali and the politics of Muslim identity. Soundings, 47, 123-129. doi: $\underline{10.3898 / 136266211795427567}$

Saeed, A. (2010). British-Asian music and cultural resistance in contemporary popular music' in R. Cere (Ed.), Post-Colonial Britain (pp. 14-26). Basingstoke: Palgrave.

Saeed, A. (2009). Israel's propaganda and its war on Gaza. The Canadian Charger. Retrieved from http://www.thecanadiancharger.com/page.php?id=5\&a=218.

Saeed, A. (2008). Between Marx and Muhammad: Class Politics and British Muslims, Soundings Online Debates. Retrieved from http://www.lwbooks.co.uk/journals/soundings/class_and_culture/saeed.html.

Saeed, A. (2007a). Media, racism and Islamophobia: the representation of Islam and Muslims in the media. Sociology Compass, 1 (2), 433-462. doi: 10.1111/j.1751-9020.2007.00039.x

Saeed, A. (2007b). Northern racism: a pilot study of racism in Sunderland. In C. Ehland (Ed.), Thinking Northern: textures of identity in the north of England (pp. 163-190). Amsterdam and New York: Rodopi. 
Saeed, A. (2007c). Malcolm X and British-Muslims: a personal reflection. Journal of Religion and Popular Culture, 16 (1). doi: 10.3138/jrpc.16.1.004

Saeed, A. (2004). 9/11 and British Muslims. In J. Carter and D. Morland (Eds.), Anti-capitalist Britain. Cheltenham: New Clarion Press.

Saeed, A. (2002). 'What's in a name?' Muhammad Ali and the Politics of Cultural Identity', Culture, Sport, Society, 5 (3), 51-72. doi: 10.1080/911094214

Saeed, A., Blain, N., and Forbes, D. (1999). New ethnic and national questions in Scotland: post-British identities among Glasgow-Pakistani teenagers. Ethnic and Racial Studies, 22 (5), 821-824. doi: 10.1080/014198799329279

Said, E. (1978). Orientalism. Abingdon: Routledge.

Sardar, Z. and Davis, M. (2002). Why do people hate America? Cambridge: Icon Books.

Sayyid, S. and Vakil, A. (2011). Thinking through Islamophobia: global perspectives. London: Hurst.

Sivanandan, A. (2009). Foreword. In L. Fekete, A suitable enemy: racism, migration and Islamophobia in Europe (pp. viii-x). London: Pluto.

Solomos, J. (2003). Race and racism in Britain (3rd ed.). Basingstoke: Palgrave.

Wayne, M., Petley, J., Murray, C., and Henderson, L. (2010.) Television news, politics and young people: generation disconnected? Basingstoke: Palgrave.

Weedon, C. (2004). Identity and culture. Maidenhead: Open University Press.

Winant, H. (2009). Just do it: notes on politics and race at the dawn of the Obama presidency. Du Bois Review: Social Science Research on Race, 6, (1), 49-70. doi: $\underline{10.1017 / S 1742058 X 09090134}$ 